\title{
Manajemen Panen Kelapa Sawit (Elaeis guineensis Jacq.) di Kebun Adolina, Serdang Bedagai, Sumatera Utara
}

\author{
Harvest Management of Oil Palm (Elaeis guineensis Jacq.) in Adolina Estate, Serdang Bedagai, \\ North Sumatera
}

\author{
Rio Elvandari Lubis dan Adolf Pieter Lontoh* \\ Departemen Agronomi dan Hortikultura, Fakultas Pertanian, Institut Pertanian Bogor \\ Jalan Meranti, Kampus IPB Dramaga, Bogor 16680, Indonesia \\ Telp. \& Faks. 62-251-8629353 e-mail agronipb@indo.net.id \\ *Penulis korespondensi: alfpiton@yahoo.com
}

Disetujui 4 Mei 2016/ Published online 9 Mei 2016

\begin{abstract}
Internship aims to improve the ability and comprehension in the management of oil palm plantation. Internship implemented in Adolina Estate. In the implementation of internship, harvest management in the oil palm harvesting was accentuated to observed and studied. Observation in harvest management consists of harvest rotation, harvest density, assessed daily production, harvester requirements, criteria of ripe harvest, harvester capacity, quality fruit, and transporting the fruit to oil palm mill. Data from observation were analyzed quantitatively using the average, percentage, and standard deviation (descriptive statistics) as well as the t-student test (comparison). The results from analyzed showed that harvest management of oil palm in Adolina Estate need to be improved. It is due to harvester capacity is lower of standard company and the high production percentage of fruits have not quality. The low capacity of harvesters affect the calculation of harvester requirements and disruption of harvest rotation. Harvest rotation is disturbed affect the high production percentage of fruits have not quality. Adolina Estate has implemented assessed harvest density quite accurately to the realization of the harvest density. The accuracy of the assessed harvest density to realization of harvest density affect the accuracy of the assessed daily production as well as calculation of harvester requirements and transport harvest.
\end{abstract}

Keywords: harvester capacity, harvest management, oil palm, harvester

\begin{abstract}
ABSTRAK
Kegiatan magang bertujuan untuk meningkatkan kemampuan dan pemahaman dalam pengelolaan perkebunan kelapa sawit. Kegiatan magang dilaksanakan di Kebun Adolina. Dalam pelaksanaan magang, manajemen panen dalam kegiatan panen kelapa sawit diutamakan untuk diamati dan dipelajari. Pengamatan dalam manajemen panen terdiri atas: rotasi panen, kerapatan panen, taksasi produksi harian, kebutuhan tenaga panen, kriteria matang panen, kapasitas pemanen, mutu buah dan pengangkutan buah ke pabrik kelapa sawit. Data yang diperoleh dianalisis secara kuantitatif menggunakan rata-rata, persentase dan standar deviasi (statistik deskriptif) serta uji t-student (komparasi). Hasil yang diperoleh menunjukkan bahwa manajemen panen kelapa sawit di Kebun Adolina perlu ditingkatkan. Hal ini karena kapasitas pemanen yang lebih rendah dari standar perusahaan dan tingginya persentase produksi buah yang tidak bermutu. Rendahnya kapasitas pemanen berpengaruh terhadap perhitungan kebutuhan tenaga panen dan terganggunya rotasi panen. Rotasi panen yang terganggu berpengaruh terhadap tingginya persentase produksi buah yang tidak bermutu. Kebun Adolina telah melaksanakan taksasi kerapatan panen yang cukup akurat terhadap kerapatan panen realisasi. Keakuratan taksasi kerapatan panen terhadap kerapatan panen realisasi berpengaruh terhadap keakuratan taksasi produksi harian serta perhitungan kebutuhan tenaga panen dan angkutan panen.
\end{abstract}

Kata kunci: kapasitas pemanen, kelapa sawit, manajemen panen, tenaga panen 


\section{PENDAHULUAN}

Kelapa sawit merupakan tumbuhan tropis yang tergolong dalam famili Palmae dan berasal dari Afrika Barat, meskipun demikian ada yang menyatakan bahwa kelapa sawit berasal dari Amerika Selatan yaitu Brazil karena lebih banyak ditemukan spesies kelapa sawit di hutan Brazil dibandingkan dengan Afrika. Pada kenyataannya, tanaman kelapa sawit tumbuh subur di luar daerah asalnya, seperti: Indonesia, Malaysia, Thailand dan Papua Nugini (Fauzi et al., 2012). Di Indonesia, kelapa sawit tumbuh subur dan mengalami perluasan areal. Hal ini terlihat dari laju pertumbuhan rata-rata luas areal kelapa sawit selama 2004-2014 sebesar 7.67\% tahun ${ }^{-1}$ dengan luas areal tahun 2014 sebesar 10956231 ha (Ditjenbun, 2015).

Kelapa sawit merupakan tanaman dengan nilai ekonomis yang cukup tinggi karena merupakan salah satu tanaman penghasil minyak nabati. Minyak nabati dihasilkan dari buah kelapa sawit, baik dalam bentuk tandan buah segar (TBS) maupun brondolan. TBS dan brondolan diolah di unit ekstraksi menjadi produk setengah jadi yang berbentuk minyak kelapa sawit (crude palm oil) dan kernel kelapa sawit (palm kernel oil). Minyak kelapa sawit dan kernel kelapa sawit dapat diolah menjadi bermacam-macam produk lanjutan dengan bermacam-macam kegunaan. Minyak kelapa sawit merupakan komoditas yang mempunyai nilai strategis karena merupakan bahan baku utama pembuatan minyak makan. Permintaan minyak makan di dalam dan luar negeri yang tinggi merupakan indikasi pentingnya peranan komoditas kelapa sawit dalam perekonomian bangsa (Fauzi et al., 2012). Hal tersebut terlihat dari laju pertumbuhan rata-rata volume ekspor kelapa sawit khususnya CPO selama 2003-2014 sebesar $12.94 \%$ tahun $^{-1}$ dan volume ekspor CPO tahun 2013 yang telah mencapai 20 580000 ton dengan nilai US $\$ 15.84$ milyar (Ditjenbun, 2015).

Produksi kelapa sawit yang baik harus dicapai untuk memenuhi kebutuhan minyak nabati yang terus meningkat sebagai akibat pertumbuhan penduduk dan peningkatan pendapatan domestik bruto. Untuk mendapatkan produksi yang baik, faktor-faktor yang mempengaruhi produksi harus dipahami dan diusahakan pada tingkat yang optimal (Pahan, 2013). Faktor-faktor tersebut adalah teknik budidaya yang baik, mulai dari pembukaan lahan, pembibitan, penanaman, pemeliharaan, pemanenan dan penanganan pasca panen.

Panen merupakan salah satu kegiatan yang penting pada pengelolaan tanaman kelapa sawit. Selain bahan tanaman dan pemeliharaan tanaman, panen juga merupakan faktor penting dalam pencapaian produksi. Keberhasilan panen sangat tergantung pada pemanen dengan kapasitas kerjanya, peralatan yang digunakan untuk panen, kelancaran transportasi serta faktor pendukung lainnya seperti: organisasi panen yang baik, keadaan areal dan insentif yang disediakan (Lubis, 2008). Menurut Fadli et al. (2006), panen adalah kegiatan pemotongan tandan buah dari pohon hingga pengangkutan ke pabrik. Urutan kegiatan panen tersebut antara lain: pemotongan pelepah, pemotongan TBS, pengutipan brondolan, pengangkutan TBS dan brondolan ke tempat pengumpulan hasil (TPH) serta pengangkutan TBS dan brondolan ke pabrik kelapa sawit (PKS).

Tujuan utama kegiatan panen kelapa sawit yaitu mencapai produktivitas TBS dan kandungan minyak yang tinggi serta mutu produksi yang baik berupa asam lemak bebas (ALB) atau free fatty acid (FFA) yang rendah. Manajemen panen kelapa sawit yang baik merupakan hal yang perlu dilakukan untuk pencapaian tujuan utama tersebut (Pahan, 2013). Komponen-komponen dalam manajemen panen tersebut antara lain: persiapan panen, organisasi panen, pelaksanaan panen dan pengawasan panen.Tujuan umum kegiatan magang adalah meningkatkan kemampuan dan pemahaman mahasiswa baik secara teknis maupun manajerial dalam pengelolaan perkebunan kelapa sawit. Tujuan khusus kegiatan magang adalah mengetahui dan mempelajari manajemen panen dalam kegiatan panen kelapa sawit.

\section{BAHAN DAN METODE}

Kegiatan magang dilaksanakan di Kebun Adolina, Serdang Bedagai, Sumatera Utara. Kegiatan ini dilaksanakan pada 9 Februari hingga 8 Juni 2015. Metode pelaksanaan magang yaitu melakukan seluruh kegiatan yang sedang berlangsung di perusahaan, baik aspek teknis maupun manajerial. Selain melakukan seluruh kegiatan di atas, pengumpulan data juga dilakukan terhadap kedua aspek tersebut. Data-data yang dikumpulkan terdiri atas data primer dan data sekunder. Kegiatan magang pada aspek teknis yang sedang berlangsung di perusahaan merupakan kegiatan-kegiatan pengelolaan perkebunan kelapa sawit mulai dari pengolahan lahan, penanaman, pemeliharaan tanaman hingga panen.

Kegiatan magang pada aspek manajerial di perusahaan terdiri atas berbagai tingkatan pekerjaan mulai dari karyawan harian, pendamping mandor dan pendamping asisten tanaman. Pelaksanaan magang pada bulan pertama adalah bekerja sebagai karyawan harian. Kegiatan yang dilakukan selama magang sebagai 
karyawan harian adalah berbagai kegiatan produksi kelapa sawit mulai dari pemeliharaan hingga panen. Pelaksanaan magang pada bulan ke-2 adalah sebagai pendamping mandor. Kegiatan yang dilakukan selama magang sebagai pendamping mandor adalah menyusun rencana kerja harian, menentukan jumlah tenaga kerja, mengarahkan dan mengawasi pekerjaan yang dilakukan oleh karyawan harian, membuat laporan harian mandor dan mengisi administrasi tingkat mandor. Pelaksanaan magang pada bulan ke-3 dan ke-4 adalah sebagai pendamping asisten tanaman. Kegiatan yang dilakukan selama magang sebagai pendamping asisten tanaman adalah membuat rencana kerja harian, mengarahkan kerja mandor serta membuat laporan harian dan administrasi tingkat afdeling.

Pengumpulan data diperoleh dengan menggunakan dua metode, yaitu metode langsung untuk data primer dan metode tidak langsung untuk data sekunder. Pengumpulan data primer diperoleh melalui praktek kerja, pengamatan, diskusi dan wawancara secara langsung di lapangan. Pengumpulan data primer difokuskan pada aspek panen yaitu pengamatan tentang manajemen panen. Pengumpulan data sekunder diperoleh dari data manajerial perusahaan. Data sekunder yang diperoleh seperti: letak geografi, wilayah administratif, luas areal konsesi, tata guna lahan, keadaan tanah, keadaan iklim selama 5 tahun terakhir, kondisi tanaman, produksi selama 5 tahun terakhir, struktur organisasi, ketenagakerjaan kebun dan peraturan atau norma baku perusahaan.

Pengamatan terhadap aspek panen kelapa sawit dilakukan untuk pengumpulan data primer. Parameter-parameter yang diamati terdiri atas: (1) Rotasi panen. Pengamatan dilakukan dengan cara mengamati rotasi panen setiap hari dalam suatu bulan dan diulang sebanyak 3 kali. (2) Kerapatan panen. Pengamatan dilakukan dengan cara mengambil 50 tanaman contoh dari populasi tanaman setiap blok yang dipanen pada suatu hari panen. Pengambilan tanaman contoh dilakukan secara acak dan diulang sebanyak 5 kali. Menurut Fadli et al. (2006), data dapat diperoleh dengan cara mengamati dan menghitung jumlah tanaman yang tandan buahnya dapat dipanen dari total tanaman yang diamati. (3) Taksasi produksi harian. Pengamatan dilakukan dengan cara mengamati taksasi produksi harian yang diperoleh dari hasil penentuan kerapatan panen dan realisasi produksi harian pada suatu hari panen. Pengamatan diulang sebanyak 5 kali. (4) Kebutuhan tenaga panen. Pengamatan dilakukan dengan cara mengamati rencana dan realisasi kebutuhan tenaga panen pada suatu hari panen dan diulang sebanyak 5 kali. Kebutuhan tenaga panen di Kebun Adolina ditentukan dengan cara menghitung rasio antara hasil perkalian dari jumlah tanaman produktif, kerapatan panen, dan berat rata-rata tandan (BRT) dengan kapasitas pemanen. (5) Kriteria matang panen. Pengamatan dilakukan dengan cara menghitung jumlah brondolan normal dan segar per tandan yang jatuh di piringan tanaman atau sekitarnya sebelum TBS dipanen. Pengamatan dilakukan pada 8 pemanen contoh dengan mengambil 5 tanaman contoh pada setiap pemanen pada suatu hari panen dan diulang sebanyak 3 kali. (6) Kapasitas pemanen. Pengamatan dilakukan dengan cara mengamati kapasitas 14 pemanen contoh pada suatu hari panen dan diulang sebanyak 5 kali. (7) Mutu buah. Pengamatan mutu buah dilakukan pada 13 pemanen contoh dengan mengambil 10 TBS contoh di TPH untuk setiap pemanen contoh pada suatu hari panen. Pengamatan dilakukan dengan cara menghitung jumlah tandan buah sangat mentah, mentah, matang dan lewat matang atau tandan kosong berdasarkan kriteria jumlah brondolan lepas yang telah ditetapkan perusahaan (Tabel 1). Pengamatan diulang sebanyak 3 kali. (8) Pengangkutan buah ke PKS. Pengamatan dilakukan dengan cara mengikuti proses pengangkutan buah hingga ke PKS pada suatu hari panen. Parameter yang diamati adalah jumlah pekerja, kebutuhan alat angkut, kapasitas angkut, jumlah alat angkut, waktu yang dibutuhkan untuk pengangkutan buah ke PKS, kecepatan angkutan, jarak pengangkutan dan kondisi jalan. Pengamatan diulang sebanyak 5 kali.

Tabel 1. Kriteria tingkat kematangan tandan buah di Kebun Adolina

\begin{tabular}{lll}
\hline Fraksi & \multicolumn{1}{c}{$\begin{array}{c}\text { Brondolan Lepas dari } \\
\text { Tandan Buah }\end{array}$} & \multicolumn{1}{c}{ Kematangan } \\
\hline F00 & Belum ada & Sangat mentah \\
F0 & $<5$ bagian luar & Mentah \\
- & $\geq 5$ bagian luar dan $<90 \%$ & Matang \\
& bagian dalam & \\
- & $\geq 90 \%$ bagian dalam & Lewat Matang atau \\
& & Tandan Kosong \\
\hline Sumber: Kantor Afdeling 2 Kebun Adolina, PTPN IV (2015)
\end{tabular}

Sumber: Kantor Afdeling 2 Kebun Adolina, PTPN IV (2015)

Data yang diperoleh dari kegiatan magang dianalisis secara kuantitatif. Analisis kuantitatif yang dilakukan adalah analisis statistik deskripif dan analisis komparasi. Analisis data secara statistik deskriptif dilakukan dengan menggunakan ratarata, persentase dan standar deviasi dari data yang diperoleh dari pengamatan dan membandingkan data tersebut dengan standar perusahaan dan studi pustaka yang mendukung. Analisis data secara komparasi dilakukan dengan uji $t$-student menggunakan software minitab 16 untuk mengetahui perbedaan antara data realisasi 
yang diperoleh dari pengamatan dan standar yang ditetapkan perusahaan.

\section{HASIL DAN PEMBAHASAN}

Unit Usaha Adolina memiliki areal seluas 8 965.69 ha dengan status Hak Guna Usaha (HGU). Luas areal terdiri atas: kebun kelapa sawit seluas 7 596 ha, kebun benih kelapa sawit seluas 62.90 ha, kebun benih kakao seluas 48 ha dan lain-lain seluas 1258.79 ha (emplasemen, perumahan karyawan dan PKS).

Berdasarkan data curah hujan tahun 2010 hingga 2014, Kebun Adolina memiliki curah hujan rata- rata sebesar $1537 \mathrm{~mm}_{\text {tahun }}{ }^{-1}$ dan hari hujan rata-rata sebesar 90 hari tahun ${ }^{-1}$. Berdasarkan sistem klasifikasi iklim Schmidth-Ferguson, Kebun Adolina memiliki rata-rata 2 bulan kering dan 8 bulan basah setiap tahun. Tipe iklim Kebun Adolina adalah tipe $\mathrm{B}$ (basah) dengan nilai $\mathrm{Q}=30 \%$.

Kebun Adolina terletak pada ketinggian 15-130 meter di atas permukaan laut. Kebun Adolina memiliki topografi datar, berombak hingga bergelombang pada sebagian besar areal dan berbukit pada sebagian kecil areal. Jenis tanah adalah typic hapludults (ultisol), aquatic tropopsamments, typic tropopsamments dan aeric endoaquents (entisol). Keasaman tanah ( $\mathrm{pH})$ Kebun Adolina tergolong agak masam yaitu sekitar 5.66.6. Kesesuaian lahan Kebun Adolina terhadap tanaman kelapa sawit adalah kelas S3 (agak sesuai).

Luas areal tanaman kelapa sawit di Kebun Adolina adalah 7596 ha. Bahan tanam yang digunakan terdiri atas tenera Marihat dan tenera Socfindo dengan komposisi masing-masing sebesar $71.65 \%$ dan $28.35 \%$. Tanaman kelapa sawit terdiri atas 16 tahun tanam berbeda, mulai dari tahun tanam 1993 hingga 2011. Komposisi umur tanaman terdiri atas $32.79 \%$ tanaman muda (4-8 tahun), $21.85 \%$ tanaman remaja (9-13 tahun), 44\% tanaman dewasa (14-20 tahun) dan $1.36 \%$ tanaman tua (>20 tahun). Rata- rata populasi per hektar adalah 137 tanaman dengan jarak tanam yang bervariasi setiap tahun tanam. Jarak tanam yang digunakan di Kebun Adolina disajikan pada Tabel 3.

Rendemen minyak kelapa sawit Kebun Adolina sebesar $24.55 \%$ dan rendemen kernel sebesar 5\%. Berdasarkan data potensi produksi tanaman kelapa sawit pada kelas kesesuaian lahan S3 Pusat Penelitian Kelapa Sawit (PPKS), Kebun Adolina memiliki potensi produktivitas sebesar 19.11 ton TBS ha ${ }^{-1} \operatorname{tahun}^{-1}$, rendemen minyak sebesar $23.5 \%$ dan rendemen kernel sebesar 5.85\% (Lubis, 2008). Hal ini menunjukkan bahwa produktivitas TBS Kebun Adolina lebih rendah dari potensi produktivitasnya. Keadaan ini juga terlihat pada Gambar 1 yang merupakan grafik perbandingan antara produktivitas dari seluruh tanaman di Kebun Adolina berdasarkan umur tanaman pada data produksi tahun 2010 hingga 2014 (Lampiran 1) dengan potensi produktivitasnya menurut PPKS. Gambar 1 menunjukkan bahwa tanaman berumur 7-21 tahun di Kebun Adolina memiliki produktivitas yang lebih rendah dari potensi produktivitasnya.

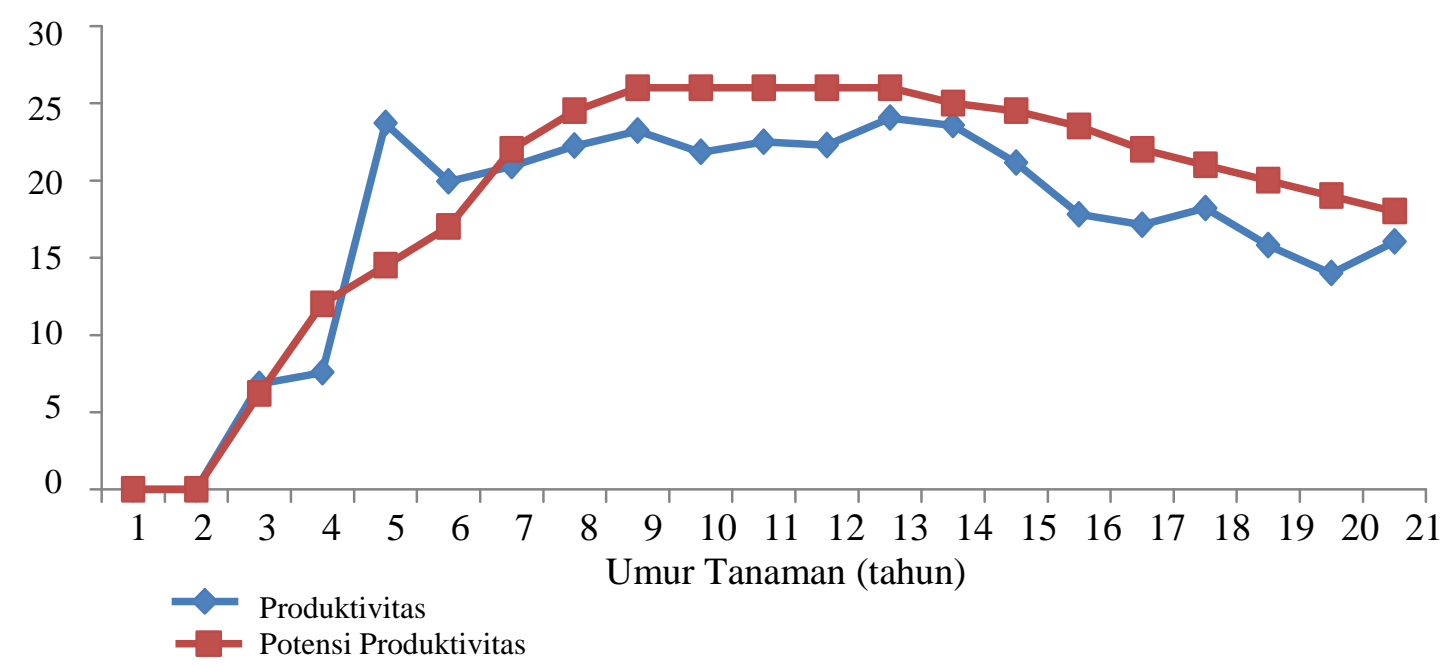

Gambar 1. Perbandingan antara produktivitas tanaman di Kebun Adolina dengan potensi produktivitas menurut PPKS pada kelas kesesuaian lahan S3

Faktor-faktor produksi seperti keadaan iklim serta serangan hama dan penyakit diduga menjadi penyebab produktivitas tanaman di Kebun
Adolina lebih rendah dari potensi produktivitasnya. Berdasarkan data curah hujan tahun 2010 hingga 2014, Kebun Adolina memiliki curah hujan yang 
berfluktuasi dengan rata-rata $1537 \mathrm{~mm}$ tahun $^{-1}$. Menurut Lubis (2008), curah hujan yang optimum untuk tanaman kelapa sawit adalah 2000 $2500 \mathrm{~mm}$ tahun $^{-1}$. Curah hujan yang rendah dapat mengakibatkan tanaman kelapa sawit mengalami defisit air yang dapat menyebabkan penurunan produksi.

Menurut Syahputra (2011), serangan hama ulat kantong dapat menyebabkan kerusakan daun karena hama ini memakan mesofil daun. Pahan (2013) menyatakan, kerusakan daun (defoliasi) akibat serangan hama ulat kantong dapat menyebabkan penurunan produksi karena proses fotosintesis tanaman terganggu.

Menurut PPKS (2014), populasi tanaman di Kebun Adolina tergolong agak heterogen karena adanya tanaman sisipan yang umurnya tidak sebanding dengan tanaman utama akibat serangan penyakit busuk pangkal batang yang disebabkan Ganoderma boninense. Menurut Lubis (2008), areal tanaman yang terinfeksi penyakit busuk pangkal batang akan mengalami penurunan populasi sebesar 1-2\% setiap tahun karena serangan penyakit ini mengakibatkan tanaman mengalami kematian. Intensitas serangan yang berat dapat mengakibatkan penurunan populasi tanaman sebesar 20-30\%. Keadaan ini akan menurunkan produktivitas kebun.

\section{Manajemen Panen Kelapa Sawit}

Panen kelapa sawit merupakan kegiatan pemotongan tandan buah dari pohon, pengutipan dan pengumpulan brondolan, hingga pengangkutan tandan buah dan brondolan ke pabrik. Tujuan panen adalah untuk memperoleh buah kelapa sawit yang matang dan bermutu baik, sehingga potensi minyak dan kernel kelapa sawit yang optimal dapat dicapai. Manajemen panen yang baik perlu dilakukan untuk mencapai tujuan panen tersebut.

Baik dan buruknya pelaksanaan aspek panen kelapa sawit di Kebun Adolina tergantung dari manajemen perusahaan. Untuk mengetahui hal tersebut dilakukan analisis terhadap komponen-komponen dari aspek panen yang merupakan hasil dari manajemen panen. Analisis dilakukan terhadap hasil pengamatan pada komponen-komponen dari aspek panen seperti: rotasi panen, kerapatan panen, taksasi produksi harian, kebutuhan tenaga panen, kriteria matang panen, kapasitas pemanen, mutu buah dan pengangkutan buah ke PKS.

Rotasi panen. Rotasi panen yang diterapkan di Kebun Adolina adalah rotasi panen 7 hari dengan sistem panen 5/7. Rotasi panen harus diterapkan secara konsisten karena rotasi panen yang sesuai dengan perkembangan buah adalah rotasi panen 7 hari (Fadli et al. 2006). Hasil pengamatan yang membandingkan antara rotasi panen realisasi dengan rotasi panen yang ditetapkan perusahaan dapat dilihat pada Tabel 5. Hasil pengamatan rotasi panen selama 3 bulan pada Tabel 5 menunjukkan bahwa rotasi panen realisasi terpendek adalah 5 hari dan rotasi panen terpanjang adalah 10 hari. Hal ini menunjukkan bahwa rotasi panen realisasi belum sesuai dengan rotasi panen yang ditetapkan perusahaan. Rotasi panen yang terlalu pendek dan panjang dapat menyebabkan kerugian produksi. Hal ini karena rotasi panen yang pendek dapat mengakibatkan rendahnya persentase buah matang yang dapat dipanen, sehingga dapat mendorong pemanen untuk memanen buah mentah dalam memenuhi basis borongnya (Pahan, 2013). Rotasi panen yang panjang dapat meningkatkan persentase buah lewat matang atau busuk (Sunarko, 2009). Menurut Fadli et al. (2006), rotasi panen yang panjang juga dapat menyebabkan tanaman terserang Marasmius sp. Keadaan ini terlihat dari mutu buah yang dihasilkan rata-rata pemanen pada Tabel 13 yaitu: $0.51 \%$ TBS bermutu sangat mentah, $6.15 \%$ TBS bermutu mentah dan $5.13 \%$ TBS bermutu lewat matang atau tandan kosong dari total TBS yang dipanen.

Tabel 5. Rotasi panen Afdeling 2 Kebun Adolina

\begin{tabular}{cccc}
\hline Bulan & $\begin{array}{c}\text { Standar } \\
\text { perusahaan }\end{array}$ & Terpendek & Terpanjang \\
\hline Maret & 7 & 6 & 8 \\
April & 7 & 5 & 10 \\
Mei & 7 & 5 & 10 \\
\hline
\end{tabular}

Menurut Fadli et al. (2006), rotasi panen dipengaruhi oleh kerapatan panen dan kapasitas pemanen. Kerapatan panen yang tinggi akan menunjukkan produksi harian yang tinggi. Produksi harian yang tinggi akan tercapai apabila pemanen memiliki kapasitas panen yang tinggi, sedangkan kapasitas pemanen yang rendah pada saat produksi harian tinggi dapat menyebabkan produksi tidak tercapai dan terjadinya rotasi panen yang panjang. Hal ini karena kapasitas pemanen yang rendah dapat mengakibatkan kapveld panen tidak dapat diselesaikan dalam sehari. Keadaan ini menyebabkan panen pada hari berikutnya masih terdapat kapveld panen hari sebelumnya. Terjadinya kondisi ini terus-menerus akan mengakibatkan rotasi panen yang panjang.

Kerapatan panen yang rendah akan menunjukkan produksi harian yang rendah. Produksi harian yang rendah akan mengakibatkan kelebihan tenaga panen. Kelebihan tenaga panen harus dimanfaatkan secara tepat. Menurut Lubis (2008), kelebihan tenaga panen dapat dialokasikan pada kegiatan pemeliharaan seperti penunasan. Kesalahan dalam pengalokasian kelebihan tenaga panen seperti mengalokasikan kelebihan tenaga panen untuk melakukan panen pada kapveld

Rio Elvandari Lubis dan Adolf Pieter Lontoh 
panen hari berikutnya akan mengakibatkan rotasi panen yang pendek.

Kerapatan panen. Perhitungan kerapatan panen bertujuan untuk memperkirakan produksi harian. Kerapatan panen ditentukan dengan cara mengambil beberapa tanaman contoh dari suatu populasi tanaman, kemudian menghitung perbandingan antara jumlah tanaman yang dapat dipanen dengan seluruh tanaman contoh. Menurut Lubis (2008), kerapatan panen harus dihitung sehari sebelum hari pelaksanaan panen. Keakuratan taksasi kerapatan panen terhadap kerapatan panen realisasi akan berpengaruh terhadap taksasi produksi harian. Hasil pengamatan yang membandingkan antara taksasi kerapatan panen dengan kerapatan panen realisasi dapat dilihat pada Tabel 6.

Tabel 6. Kerapatan panen afdeling 2 kebun Adolina

\begin{tabular}{|c|c|c|c|c|c|}
\hline \multirow{2}{*}{ Hari panen } & \multicolumn{3}{|c|}{ Tanaman } & \multicolumn{2}{|c|}{ Kerapatan panen } \\
\hline & Produktif & Contoh & Contoh dapat dipanen & Taksasi & Realisasi \\
\hline Senin & 27934 & 600 & 90 & $1: 7$ & $1: 7$ \\
\hline Selasa & 20443 & 450 & 68 & $1: 7$ & $1: 8$ \\
\hline Rabu & 24095 & 400 & 48 & $1: 8$ & $1: 8$ \\
\hline Kamis & 24130 & 450 & 56 & $1: 8$ & $1: 8$ \\
\hline Jumat & 22563 & 400 & 46 & $1: 9$ & $1: 10$ \\
\hline Rata-rata & 23833 & 420 & 62 & $1: 8^{\mathrm{a}}$ & $1: 8^{\mathrm{a}}$ \\
\hline
\end{tabular}

Hasil pengamatan pada Tabel 6 menunjukkan kerapatan panen rata-rata adalah 1:8. Kerapatan panen 1:8 berarti dari rata-rata setiap 8 tanaman kelapa sawit akan ditemukan satu tandan buah matang. Menurut Tobing dalam Akbar (2008), nilai kerapatan panen $\leq 1: 4$ menunjukkan produksi tinggi, sedangkan nilai kerapatan panen 1:5 hingga 1:7 menunjukkan produksi sedang. Hal tersebut menunjukkan bahwa Kebun Adolina sedang mengalami produksi yang rendah. Kebun Adolina sedang mengalami produksi yang rendah diduga karena terjadi bulan kering selama 3 bulan berturut-turut pada awal tahun 2014. Menurut Sunarko (2014), terjadinya bulan kering $\geq 3$ bulan berturut-turut pada pertanaman kelapa sawit akan mempengaruhi produksi tanaman tahun berikutnya. Lubis (2008) menyatakan, bulan kering yang panjang dapat mengakibatkan defisit air terhadap tanaman kelapa sawit. Defisit air tersebut dapat mengakibatkan pertumbuhan dan produksi tanaman terganggu yang berlangsung selama 2-3 tahun ke depan. Hasil uji-t pada Tabel 6 yang membandingkan kerapatan panen taksasi dengan kerapatan panen realisasi menunjukkan hasil yang tidak berbeda nyata pada taraf 5\%. Hal tersebut menunjukkan bahwa perhitungan kerapatan panen yang dilakukan cukup akurat terhadap kerapatan panen realisasi.

Taksasi produksi. Taksasi produksi harus ditentukan sehari sebelum hari pelaksanaan panen. Hal tersebut dilakukan untuk menentukan kebutuhan tenaga panen, angkutan panen dan rencana olah pabrik. Taksasi produksi harian ditentukan berdasarkan luas areal atau jumlah tanaman produktif yang akan dipanen, kerapatan panen taksasi dan berat rata-rata tandan (BRT). Keakuratan taksasi produksi harian terhadap realisasi produksi harian akan berpengaruh terhadap perhitungan kebutuhan tenaga panen dan angkutan panen. Hasil pengamatan yang membandingkan antara taksasi produksi harian dengan realisasi produksi harian dapat dilihat pada Tabel 7.

Tabel 7. Taksasi produksi harian afdeling 2 kebun Adolina

\begin{tabular}{lcccccc}
\hline Hari panen & Luas areal (ha) & $\begin{array}{c}\text { Tanaman } \\
\text { produktif }\end{array}$ & $\begin{array}{c}\text { Kerapatan } \\
\text { panen }\end{array}$ & BRT (kg) & $\begin{array}{c}\text { Taksasi } \\
\text { produksi (kg) }\end{array}$ & $\begin{array}{c}\text { Realisasi } \\
\text { produksi (kg) }\end{array}$ \\
\hline Senin & 212.22 & 27934 & $1: 7$ & 9.42 & 34893 & 31401 \\
Selasa & 159.61 & 20443 & $1: 7$ & 10.56 & 31912 & 24898 \\
Rabu & 200.00 & 24095 & $1: 8$ & 11.13 & 32866 & 33121 \\
Kamis & 176.00 & 24130 & $1: 8$ & 12.00 & 36770 & 36036 \\
Jumat & 164.00 & 22563 & $1: 9$ & 11.63 & 31060 & 25589 \\
\hline Rata-rata & 170.77 & 23833 & $1: 8$ & 10.95 & $33500^{\mathrm{a}}$ & $30209^{\mathrm{a}}$ \\
\hline
\end{tabular}

Keterangan: Angka-angka yang diikuti huruf yang sama pada baris yang sama tidak berbeda nyata berdasarkan uji-t pada taraf 5\%.

Menurut Sunarko (2009), taksasi produksi bertujuan untuk memudahkan pengaturan dan pelaksanaan pekerjaan panen di kebun dan pengolahan di pabrik serta penyediaan dan pengaturan transportasi buah. Karyawan yang melakukan pekerjaan menentukan 
taksasi produksi harus memiliki ketelitian yang tinggi. Kesalahan dalam menentukan taksasi produksi dapat mempengaruhi efisiensi penggunaan tenaga panen, angkutan panen dan pengolahan pabrik. Menurut Lubis (2008), taksasi produksi harian harus dilakukan oleh mandor panen. Hal ini karena mandor panen memiliki pengalaman yang tinggi dalam menentukan tingkat kematangan buah. Hasil uji-t pada Tabel 7 yang membandingkan taksasi produksi harian dengan realisasi produksi harian menunjukkan hasil yang tidak berbeda nyata pada taraf $5 \%$. Hal tersebut menunjukkan bahwa taksasi produksi harian cukup akurat terhadap realisasi produksi.

Kebutuhan tenaga panen. Tenaga panen di Kebun Adolina dibagi menjadi beberapa kemandoran panen. afdeling 2 kebun Adolina memiliki 2 kemandoran panen dengan 59 tenaga panen (Tabel 8).

Tabel 8. Jumlah tenaga panen di Afdeling 2

\begin{tabular}{|c|c|c|}
\hline $\begin{array}{l}\text { Kemandoran } \\
\text { panen }\end{array}$ & $\begin{array}{l}\text { Status tenaga } \\
\text { panen }\end{array}$ & $\begin{array}{l}\text { Jumlah tenaga } \\
\text { panen (orang) }\end{array}$ \\
\hline \multirow[t]{2}{*}{ Mandor panen 1} & $\begin{array}{l}\text { Karyawan } \\
\text { tetap }\end{array}$ & 14 \\
\hline & $\begin{array}{l}\text { Buruh harian } \\
\text { lepas }\end{array}$ & 13 \\
\hline Mandor panen 2 & $\begin{array}{l}\text { Buruh harian } \\
\text { lepas }\end{array}$ & 32 \\
\hline Total & & 59 \\
\hline
\end{tabular}

Sumber: Kantor afdeling 2 kebun Adolina (2015)

Manajemen dalam penggunaan tenaga panen harus dilakukan dengan baik agar jumlah tenaga panen yang dimiliki perusahaan mampu memenuhi kebutuhan tenaga panen setiap hari. Kebutuhan tenaga panen ditentukan sehari sebelum hari pelaksanaan panen. Berdasarkan SOP PTPN IV, kebutuhan tenaga panen ditentukan berdasarkan kapasitas pemanen yaitu $1200 \mathrm{~kg}$ TBS pemanen ${ }^{-1}$. Cara perhitungan kebutuhan tenaga panen Afdeling 2 Kebun Adolina adalah sebagai berikut:

\section{Kebutuhan $=\Sigma$ Tan. Produktif $\mathrm{x} \mathrm{KP} \times$ BRT tenaga panen Kapasitas pemanen}

Kebutuhan tenaga panen harus direncanakan dengan baik karena kekurangan tenaga panen dapat berpengaruh terhadap pencapaian produksi dan kelebihan tenaga panen dapat berpengaruh terhadap biaya panen. Kebutuhan tenaga panen dipengaruhi oleh kondisi areal kebun, umur tanaman dan kapasitas pemanen. Oleh karena itu, faktor-faktor tersebut harus dipertimbangkan dengan baik. Tabel 9 menunjukkan hasil pengamatan yang membandingkan antara kebutuhan tenaga panen 150 rencana yang dihitung berdasarkan SOP dengan kebutuhan tenaga panen realisasi.

Tabe 9. Kebutuhan tenaga panen di Afdeling 2

\begin{tabular}{|c|c|c|}
\hline \multirow{2}{*}{ Hari panen } & \multicolumn{2}{|c|}{ Kebutuhan tenaga panen } \\
\hline & Rencana (SOP) & Realisasi \\
\hline Senin & 26 & 53 \\
\hline Selasa & 21 & 48 \\
\hline Rabu & 28 & 46 \\
\hline Kamis & 30 & 53 \\
\hline Jumat & 21 & 34 \\
\hline Rata-rata & $25^{\mathrm{a}}$ & $47^{\mathrm{a}}$ \\
\hline Keterangan: & $\begin{array}{l}\text { Angka-angka yang diiku } \\
\text { pada baris yang sama be } \\
\text { berdasarkan uji-t pada ta }\end{array}$ & $\begin{array}{l}\text { yang berbeda } \\
\text { Jata }\end{array}$ \\
\hline
\end{tabular}

Tenaga panen merupakan salah satu sumber daya yang sangat dibutuhkan dalam pekerjaan panen. Kebutuhan tenaga panen harus diperhitungkan dengan baik pada saat membuat rencana panen. Menurut Fadli et al. (2006), menentukan kebutuhan tenaga panen berdasarkan pada keadaan topografi kebun, kerapatan panen dan umur tanaman. Hasil uji-t pada Tabel 9 yang membandingkan kebutuhan tenaga panen rencana yang dihitung berdasarkan SOP perusahaan dengan kebutuhan tenaga panen realisasi menunjukkan hasil yang berbeda nyata pada taraf 5\%. Hasil tersebut menunjukkan bahwa kapasitas pemanen standar perusahaan tidak dapat menjadi acuan dalam memperhitungkan kebutuhan tenaga panen di Kebun Adolina. Hal ini karena rata-rata pemanen hanya memanen buah sampai memperoleh basis borong panen, sehingga rata-rata kapasitas pemanen di Kebun Adolina masih lebih rendah dari kapasitas pemanen standar perusahaan. Keadaan ini mengakibatkan basis borong menjadi acuan dalam menentukan kebutuhan tenaga panen di Kebun Adolina.

Hasil pengamatan pada Tabel 9 menunjukkan rata-rata kebutuhan tenaga panen di Afdeling 2 Kebun Adolina adalah 47 orang. Jumlah ini masih lebih kecil dibandingkan jumlah tenaga panen yang dimiliki Afdeling 2 Kebun Adolina (Tabel 8). Menurut Fadli et al. (2006), kelebihan tenaga panen dapat digunakan untuk kegiatan penunasan atau pemeliharaan lainnya.

Kriteria matang panen. Buah kelapa sawit (brondolan) akan lepas dari tandannya apabila telah mencapai kematangan maksimal. Menurut Sunarko (2014), buah yang telah matang maksimal akan berwarna merah atau oranye. Hal tersebut yang dijadikan indikasi dalam menentukan kematangan buah. PTPN IV menggunakan kriteria 5 brondolan normal dan segar per tandan yang jatuh di piringan tanaman sebagai indikasi dalam menentukan kematangan buah. Pemanen harus mengikuti kriteria matang panen tersebut agar buah yang

Rio Elvandari Lubis dan Adolf Pieter Lontoh 
dipanen memiliki mutu sesuai target perusahaan. Hasil pengamatan terhadap kriteria matang panen dapat dilihat pada Tabel 10.

Hasil pengamatan pada Tabel 10 menunjukkan rata-rata pemanen memanen TBS yang memiliki brondolan normal dan segar per tandan yang jatuh di piringan dengan nilai tengah $8.48 \pm 1.24$. Hal tersebut menunjukkan bahwa ratarata pemanen di Kebun Adolina telah menerapkan kriteria matang panen sesuai standar perusahaan dalam memanen TBS. Kriteria matang panen ini tidak dapat menjadi pedoman baku bagi pemanen. Hal tersebut karena buah yang lepas dari tandannya (brondolan) dapat tersangkut di spikelet tandan ataupun di ketiak pelepah. Selain itu, pada kebun-kebun yang rawan pencurian buah, piringan tanaman akan kelihatan bersih dari brondolan. Oleh karena itu, pemanen harus memeriksa seluruh tandan pada setiap tanaman untuk menghindari adanya buah matang yang tidak dipanen. Menurut Risza (1994), buah di ujung tandan juga harus dijolok untuk memastikan buah sudah lepas atau membrondol dari tandannya.

Tabel 10. Kriteria matang panen di Kebun Adolina berdasarkan brondolan yang jatuh di piringan atau sekitar tanaman

\begin{tabular}{|c|c|c|c|c|}
\hline \multirow{2}{*}{$\begin{array}{c}\text { Nomor } \\
\text { pemanenan }\end{array}$} & \multicolumn{3}{|c|}{ Hari ke- } & \multirow{2}{*}{ Rata-rata } \\
\hline & 1 & 2 & 3 & \\
\hline \multicolumn{5}{|c|}{----------Brondolan---------- } \\
\hline 1 & 10.20 & 7.40 & 8.00 & 8.53 \\
\hline 3 & 8.80 & 14.00 & 5.40 & 9.40 \\
\hline 4 & 5.60 & 6.60 & 5.80 & 6.00 \\
\hline 8 & 13.60 & 5.60 & 5.80 & 8.33 \\
\hline 9 & 8.60 & 9.80 & 8.40 & 8.93 \\
\hline 11 & 15.20 & 9.80 & 5.80 & 10.27 \\
\hline 12 & 10.20 & 7.60 & 6.00 & 7.93 \\
\hline 23 & 10.80 & 9.00 & 5.60 & 8.47 \\
\hline $\begin{array}{l}\text { Rata-rata } \pm \\
\text { SD }\end{array}$ & & 072 & $5 \pm 1$. & .24 \\
\hline
\end{tabular}

Kapasitas pemanen . Kapasitas pemanen adalah kemampuan pemanen memanen buah setiap hari yang ditentukanberdasarkan total berat buah yang mampu dipanen. Pemanen harus mencapai basis borong dalam memanen buah setiap hari. Apabila basis borong tidak tercapai, pemanen akan mendapatkan denda dari perusahaan. Tabel 11 menunjukkan hasil pengamatan kapasitas pemanen di Kebun Adolina.

Jumlah tenaga panen yang dimiliki perusahaan tidak akan mampu mencapai produksi yang optimal apabila kapasitas kerjanya rendah. Oleh karena itu, perusahaan harus menetapkan standar untuk kapasitas pemanen. Kapasitas pemanen ditentukan berdasarkan kondisi areal kebun dan tanaman. Kapasitas pemanen berdasarkan SOP PTPN IV adalah $1200 \mathrm{~kg}$ TBS pemanen $^{-1}$ hari $^{-1}$. Uji-t pada Tabel 12 yang membandingkan kapasitas pemanen rata-rata dengan kapasitas pemanen standar perusahaan dilakukan untuk mengetahui kinerja pemanenpemanen di Kebun Adolina.

Tabel 11. Kapasitas pemanenan di Kebun Adolina

\begin{tabular}{crc}
\hline Nomor & Kapasitas & Basis Borong \\
\hline 3 & 1157 & 750 \\
4 & 1305 & 750 \\
5 & 1352 & 750 \\
9 & 1144 & 690 \\
12 & 1004 & 690 \\
16 & 785 & 800 \\
23 & 751 & 690 \\
25 & 757 & 690 \\
28 & 1316 & 800 \\
34 & 774 & 800 \\
37 & 1232 & 800 \\
40 & 1217 & 800 \\
47 & 680 & 800 \\
50 & 1250 & 800 \\
\hline Rata-rata \pm & $1051.71 \pm 249.45$ & $757.86 \pm 48.86$ \\
\hline
\end{tabular}

Hasil pengamatan pada Tabel 11 menunjukkan bahwa kapasitas pemanen rata-rata lebih tinggi dibandingkan basis borong panen ratarata, tetapi hasil uji-t pada Tabel 12 yang membandingkan kapasitas pemanen rata-rata terhadap kapasitas pemanen standar perusahaan menunjukkan hasil yang berbeda nyata pada taraf 5\%. Hal tersebut menunjukkan bahwa kapasitas pemanen di Kebun Adolina telah mencapai basis borong, tetapi kapasitas tersebut masih di bawah kapasitas pemanen standar perusahaan yaitu 1200 $\mathrm{kg}$ TBS.

Tabel 12. Hasil uji-t kapasitas pemanen terhadap kapasitas pemanen standar perusahaan

\begin{tabular}{cccc}
\hline \multicolumn{2}{c}{ Kapasitas pemanenan $(\mathrm{kg})$} & & \\
\cline { 1 - 2 } Rata-rata & $\begin{array}{c}\text { Standar } \\
\text { perusahaan }\end{array}$ & t-hitung & $\operatorname{Pr}>\mathrm{t}$ \\
\hline 1051.71 & 1200 & -2.22 & $0.044^{*}$ \\
\hline Keterangan $* *$ * berbeda nyata pada $\alpha=5 \%$ &
\end{tabular}

Keterangan : * ${ }^{*}$ berbeda nyata pada $\alpha=5 \%$

Menurut Setyamidjaja (2006), setiap pemanen dapat memanen antara 400-900 kg TBS dalam sehari bergantung pada produksi per hektar yang berkaitan dengan umur tanaman, topografi areal, kerapatan tanaman, insentif yang disediakan dan musim panen (panen puncak atau panen rendah). Hal ini menunjukkan bahwa kapasitas pemanen yang ditetapkan PTPN IV cukup tinggi. Menurut Lastinawati (2014), untuk memperoleh kapasitas panen yang tinggi dapat dipengaruhi oleh pengalaman kerja, keterampilan, kemampuan dan kekuatan fisik pemanen. Risza (1994) menyatakan, kebijakan sistem premi panen 
juga harus mendukung sistem panen yang ada, sehingga dapat mendorong pemanen untuk mencapai kapasitas yang tinggi dengan tidak mengabaikan syarat-syarat dan peraturan panen yang telah ditetapkan perusahaan.

Mutu buah. Pengamatan mutu buah hasil panen dilakukan terhadap 13 pemanen contoh untuk mengetahui kinerja pemanen-pemanen di Kebun Adolina. Tabel 13 menunjukkan hasil pengamatan terhadap mutu buah yang diperoleh rata-rata pemanen setiap hari. Hasil pengamatan terhadap mutu buah hasil panen pada Tabel 13 menunjukkan bahwa rata-rata mutu buah (TBS) yang diperoleh pemanen di Kebun Adolina adalah $88.21 \%$ TBS matang, $0.51 \%$ TBS sangat mentah, $6.15 \%$ TBS mentah dan 5.13\% TBS lewat matang atau tandan kosong dari total TBS contoh yang dipanen. Standar mutu buah yang ditetapkan adalah $100 \%$ TBS bermutu matang dari seluruh TBS yang dipanen. Hal ini menunjukkan bahwa mutu buah hasil panen di Kebun Adolina perlu ditingkatkan. Menurut Siahaan dan Erningpraja (2005), untuk menjamin perolehan TBS yang berkualitas, pengawasan mutu panen perlu dilakukan secara intensif dan reguler. Pengawasan tersebut antara lain rotasi panen dan pemanenan TBS pada tingkat kematangan yang optimal.

Kerugian akibat memotong buah mentah adalah kehilangan sebagian potensi produksi minyak karena rendemen minyak dari buah mentah sangat rendah (Pahan, 2013). Lubis (2008) menyatakan buah yang terlalu matang juga akan menimbulkan kerugian atas mutu minyak yang diperoleh karena kandungan ALB yang tinggi. Faktor-faktor yang mempengaruhi buah mentah terpanen adalah kurangnya ketelitian pemanen dalam menentukan buah matang, rendahnya kapasitas pemanen mengakibatkan buah mentah dipanen untuk mencapai basis borong dan penerapan denda yang kurang baik. Faktorfaktor yang mempengaruhi adanya buah lewat matang atau tandan kosong dipanen karena rotasi panen yang tidak sesuai dengan standar perusahaan dan adanya buah matang yang tidak dipanen pada rotasi panen sebelumnya.

Tabel 13. Mutu buah hasil panen afdeling 2 Kebun Adolina

\begin{tabular}{|c|c|c|c|c|}
\hline \multirow[b]{2}{*}{ Nomor pemanen } & \multicolumn{4}{|c|}{ Mutu buah (TBS) } \\
\hline & Sangat mentah & Mentah & Matang & $\begin{array}{l}\text { Lewat matang atau } \\
\text { tandan kosong }\end{array}$ \\
\hline 3 & 0.00 & 0.00 & 10.00 & 0.00 \\
\hline 8 & 0.00 & 0.33 & 9.00 & 0.67 \\
\hline 9 & 0.00 & 0.33 & 8.67 & 1.00 \\
\hline 10 & 0.00 & 1.00 & 8.67 & 0.33 \\
\hline 11 & 0.00 & 0.67 & 9.00 & 0.33 \\
\hline 12 & 0.00 & 0.33 & 9.33 & 0.33 \\
\hline 13 & 0.00 & 0.33 & 9.00 & 0.67 \\
\hline 21 & 0.00 & 0.33 & 8.67 & 1.00 \\
\hline 23 & 0.00 & 0.00 & 9.67 & 0.33 \\
\hline 24 & 0.00 & 0.67 & 8.67 & 0.67 \\
\hline 25 & 0.33 & 0.00 & 9.00 & 0.67 \\
\hline 28 & 0.00 & 1.00 & 8.67 & 0.33 \\
\hline 37 & 0.33 & 3.00 & 6.33 & 0.33 \\
\hline Rata-rata & 0.05 & 0.62 & 8.82 & 0.51 \\
\hline Persentase (\%) & 0.51 & 6.15 & 88.21 & 5.13 \\
\hline Standar perusahaan $(\%)$ & 0.00 & 0.00 & 100.00 & 0.00 \\
\hline
\end{tabular}

Pengangkutan buah ke PKS. Kegiatan akhir dari proses pemanenan kelapa sawit. Kebun Adolina menggunakan truk sebagai alat angkut panen ke PKS. Setiap afdeling memiliki jumlah alat angkut yang berbeda. Semakin jauh jarak antara afdeling ke PKS, maka semakin banyak jumlah alat angkut yang dimiliki suatu afdeling. Angkutan panen tersebut disediakan oleh pemborong. Kebutuhan angkutan panen setiap hari ditentukan pada hari sebelumnya agar pemborong dapat menyediakan dan mempersiapkan jumlah angkutan panen yang dibutuhkan. Kebutuhan angkutan panen ditentukan berdasarkan taksasi produksi dan kapasitas angkut. Kapasitas angkut rata-rata truk di Kebun Adolina adalah 6 ton trip ${ }^{-1}$ (Tabel 14).

Tabel 14. Kebutuhan angkutan panen Afdeling 2

\begin{tabular}{lcc}
\hline $\begin{array}{c}\text { Ulangan } \\
\text { (hari panen) }\end{array}$ & $\begin{array}{c}\text { Taksasi produksi } \\
\text { (ton) }\end{array}$ & $\begin{array}{c}\text { Kebutuhan } \\
\text { angkutan panen } \\
\text { (trip) }\end{array}$ \\
\hline Senin & 34.89 & 6 \\
Selasa & 31.91 & 5 \\
Rabu & 32.87 & 6 \\
Kamis & 36.77 & 6 \\
Jumat & 31.06 & 5 \\
\hline Rata-rata & 33.50 & 6 \\
\hline
\end{tabular}

Buah hasil panen harus segera diolah di PKS untuk menjaga kualitas minyak yang 
dihasilkan. Semakin lama rentang waktu antara pemanenan dan pengolahan buah, maka dapat meningkatkan kandungan ALB yang dapat menurunkan kualitas minyak. Menurut Alfiah dan Susanto (2015), salah satu faktor eksternal yang menyebabkan peningkatan kadar ALB yang relatif tinggi dalam minyak kelapa sawit adalah keterlambatan dalam pengumpulan dan pengangkutan buah. Untuk menghindari hal tersebut, maka pengangkutan buah ke PKS harus diatur dengan baik. Koordinasi antara PKS dan afdeling harus dilakukan dengan baik agar pengolahan di PKS dan pengangkutan buah dapat berjalan lancar. Faktor-faktor yang mempengaruhi kelancaran proses pengangkutan buah tersebut antara lain: jumlah angkutan panen dan pemuat buah, kapasitas angkutan panen dan pemuat buah, jarak kebun ke PKS serta kondisi jalan dan angkutan panen. Hasil pengamatan pengangkutan buah dari kebun ke PKS dapat dilihat pada Tabel 15 .

Tabel 15. Kebutuhan waktu pengangkutan buah per trip Afdeling 2

\begin{tabular}{ll}
\hline \multicolumn{1}{c}{ Kegiatan } & $\begin{array}{c}\text { Lama kegiatan } \\
\text { (menit) }\end{array}$ \\
\hline Truk berangkat ke kapveld panen & 13 \\
Pemuatan buah dari kebun ke truk & 70 \\
Pengangkutan buah ke PKS & 13 \\
Bongkar muat secara manual & 16 \\
\hline Total & 112 \\
\hline
\end{tabular}

Hasil pengamatan pengangkutan buah dari Afdeling 2 Kebun Adolina ke PKS menunjukkan bahwa Afdeling 2 Kebun Adolina memiliki 2 angkutan buah berupa truk. Setiap truk terdapat 4 orang petugas, yang terdiri atas: 1 orang $\mathrm{P} 2 \mathrm{~B}, 1$ orang supir dan 2 orang pemuat buah. Setiap truk dapat melakukan pengangkutan buah lebih dari 1 trip hari ${ }^{-1}$. Kebutuhan angkutan panen (trip) per hari di afdeling dibagi rata untuk kedua truk. Apabila kebutuhan angkutan panen pada suatu hari panen memiliki angka ganjil seperti hari panen selasa yaitu 5 truk atau trip (Tabel 14), maka salah satu dari kedua truk mendapatkan trip pengangkutan buah yang lebih banyak. Hal tersebut sesuai kesepakatan dari kedua truk. Misalkan, truk A melakukan pengangkutan buah sebanyak 3 trip dan truk B melakukan pengangkutan buah sebanyak 2 trip pada minggu ini, maka truk A akan melakukan pengangkutan buah sebanyak 2 trip dan truk B melakukan pengangkutan buah sebanyak 3 trip pada minggu berikutnya. Waktu yang dibutuhkan per trip pengangkutan buah dari Afdeling 2 Kebun Adolina ke PKS adalah 112 menit (Tabel 15). Rata-rata kebutuhan angkutan panen adalah 6 trip hari ${ }^{-1}$ (Tabel 14), berarti setiap truk melakukan pengangkutan buah sebanyak 3 trip hari $^{-1}$. Artinya, waktu yang dibutuhkan untuk menyelesaikan pengangkutan buah dalam sehari adalah sekitar 336 menit atau 5.6 jam. Waktu ini merupakan waktu yang cukup baik dalam pelaksanaan pengangkutan buah ke PKS karena pengolahan buah harus sudah dilaksanakan paling lambat 8 jam setelah buah dipanen untuk menghindari meningkatnya kandungan ALB yang dapat menurunkan kualitas minyak (Setyamidjaja, 2006).

\section{KESIMPULAN}

Kegiatan magang memberikan wawasan dan pengalaman baik secara teknis maupun manajerial dalam mengelola perkebunan kelapa sawit. Hasil yang diperoleh dari kegiatan ini menunjukkan bahwa pengelolaan perkebunan kelapa sawit di Kebun Adolina terutama aspek panen perlu ditingkatkan. Hal ini karena kapasitas pemanen yang lebih rendah dari standar perusahaan dan tingginya persentase produksi buah yang tidak bermutu. Rendahnya kapasitas pemanen berpengaruh terhadap perhitungan kebutuhan tenaga panen dan terganggunya rotasi panen. Rotasi panen yang terganggu berpengaruh terhadap tingginya persentase produksi buah yang tidak bermutu. Kebun Adolina telah melaksanakan taksasi kerapatan panen yang cukup akurat terhadap kerapatan panen realisasi. Keakuratan taksasi kerapatan panen terhadap kerapatan panen realisasi berpengaruh terhadap keakuratan taksasi produksi harian serta perhitungan kebutuhan tenaga panen dan angkutan panen.

\section{DAFTAR PUSTAKA}

Akbar, A. 2008. Manajemen panen di perkebunan kelapa sawit (Elaeis guineensis Jacq.) Pantai Bunai Estate, PT Sajang Heulang, Minamas Plantation, Tanah Bumbu, Kalimantan Selatan [skripsi]. Bogor (ID): Institut Pertanian Bogor.

Alfiah, C., Susanto, W.H. 2015. Penanganan pascapanen kelapa sawit (penyemprotan $\mathrm{CaCl} 2$ dan kalium sorbat terhadap mutu crude palm oil). J Pangan dan Agroindustri. 3(1): 61-72.

[Ditjenbun] Direktorat Jenderal Perkebunan. 2015. Pertumbuhan areal kelapa sawit meningkat [Internet]. Jakarta (ID): Direktorat Jenderal Perkebunan. [diunduh 2015 Januari 20]. Tersedia pada: http://ditjenbun.pertanian.go.id. 
Fadli, M.L., Sutarta, E.S., Darmosarkoro, W., Purba, P., Ginting, E.N. 2006. Panen pada Tanaman Kelapa Sawit. Medan (ID): Pusat Penelitian Kelapa Sawit.

Fauzi, Y., Widyastuti, Y.E., Satyawibawa, I., Paeru, R.H. 2012. Kelapa Sawit: Budidaya, Pemanfaatan Hasil dan Limbah, Analisis Usaha dan Pemasaran. Jakarta (ID): Penebar Swadaya.

Lastinawati, E. 2014. Faktor-faktor yang mempengaruhi pendapatan buruh panen kelapa sawit di PTP Mitra Ogan Kecamatan Peninjauan Kabupaten Ogan Komering Ulu. JI AgrIBA. Edisi September 2: $140-145$.

Lubis, A.U. 2008. Kelapa Sawit (Elaeis guineensis Jacq.) di Indonesia Ed ke-2. Medan (ID): Pusat Penelitian Kelapa Sawit.

Pahan, I. 2013 . Panduan Lengkap Kelapa Sawit. Jakarta (ID): Penebar Swadaya.

[PPKS] Pusat Penelitian Kelapa Sawit. 2014. Rekomendasi Pemupukan Tanaman Kelapa Sawit Kebun Adolina, PT Perkebunan Nusantara IV (Persero) Tahun
2015. Medan (ID): Pusat Penelitian Kelapa Sawit.

Risza, S. 1994. Kelapa Sawit Upaya Peningkatan Produktivitas. Yogyakarta (ID): Kanisisus. Setyamidjaja D. 2006. Kelapa Sawit. Yogyakarta (ID): Kanisius.

Siahaan, D., Erningpraja, L. 2005. Penerapan good agriculture practice dan good manufacture practice dalam meningkatkan mutu dan keamanan pangan minyak kelapa sawit. $J$ Penelitian Kelapa Sawit. 13(3): 109-118.

Sunarko. 2009. Budidaya dan Pengelolaan Kebun Kelapa Sawit dengan Sistem Kemitraan. Jakarta (ID): Agromedia Pustaka.

Sunarko. 2014. Budidaya Kelapa Sawit di Berbagai Jenis Lahan. Jakarta (ID): Agromedia Pustaka.

Syahputra, E. 2011. Aktivitas dan keefektifan insektisida berbahan aktif majemuk thiodicarb dan triflumuron terhadap hama ulat kantong (Metisa plana) pada tanaman kelapa sawit. J Teknol Perkebunan \& PSDL. 1(2): 1-8. 